Nig. J. Biotech. Vol. 37(1): 38-45 (June 2020)

ISSN: 01891731

Available online at

http://www.ajol.info/index.php/njb/index

and www.biotechsocietynigeria.org

DOI: https://dx.doi.org/10.4314/njb.v37i1.4

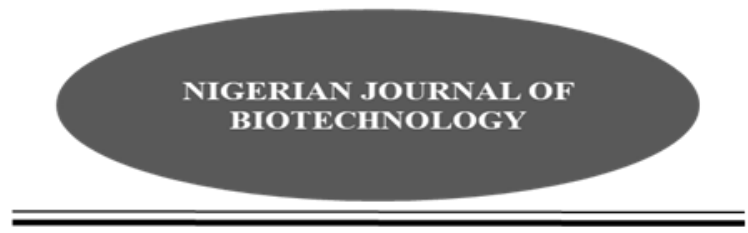

\title{
Microsatellite markers-based characterisation of elephant grass (Pennisetum purpureum) harvested from selected locations in South-West Nigeria
}

\author{
${ }^{1}$ Okukenu, O. A., ${ }^{1}$ Olajide, A. A., ${ }^{1}$ Dele, P. A., ${ }^{2}$ Wheto, M., ${ }^{1}$ Akinyemi, B. T., \\ 1Jolaosho, A. O., ${ }^{1}$ Jokosenumi, B. O. and ${ }^{1}$ Shonde, T. J.
}

${ }^{1}$ Department of Pasture and Range Management

College of Animal Science and Livestock Production

Federal University of Agriculture, Abeokuta, Ogun State, Nigeria. P.M.B 2240

2Department of Animal Breeding and Genetic

College of Animal Science and Livestock Production

Federal University of Agriculture, Abeokuta, Ogun State, Nigeria. P.M.B 2240

\begin{abstract}
This study was carried out to characterise Pennisetum purpureum harvested from some selected locations in S outh-W estern Nigeria using microsatellite markers. Leaf parts of growing young elephant grass (Pennisetum purpureum) were harvested and immediately preserved in ethanol solution before DNA extraction. Two (2) SSR primers (CTM59 and Xtxp278) were used to assess genetic diversity in Pennisetum purpureum. The result shows that $72 \%$ of the molecular variations in the elephant grass exists within the population with $\mathbf{2 8 \%}$ among the population; there were no unique characteristics among the Nine (9) populations. Nei genetic index ranged from 0.067 (lowest) observed between Isokan and Odeda populations to 0.158 (highest), between Ifedore and Ikoyi Populations. Morphological characterization showed moderate diversity with two major clusters and one minor cluster.
\end{abstract}

Keyword: Elephant grass; cultivars; locations; markers

\section{Introduction}

Elephant grass (Pennisetum purpureum Schum), a tetraploid $(2 n=4 x=28)$ perennial grass capable of producing high biomass and withstanding repeated cutting, was introduced into India from sub-Saharan Africa during the early part of $20^{\text {th }}$ century. Elephant grass has a genome formula $A A, B B$, where $A A$ is homologous to the $A A$ genome of pearl millet $(2 n=2 x=14)$ (Pennisetum glaucum (L.) R. Br.) (Jauhar, 1981). Because the species exhibits broad morphological variation and cross-pollinates, Elephant grass is a valuable source of genetic variation for pearl millet (Burton, 1999). Extensive differences exist among elephant grass genotypes of similar clones in any particular orchard especially with respect to leaf shape, colour, eating quality and texture (Singh et. al., 2009).

Genetic diversity and genetic differentiation among populations are constrained by forms like genetic drift, inbreeding, gene flow, recombination, mutation and selection (Loveless and Hamrick, 1984). Abiotic and biotic conditions have the potential to increase genetic differentiation within and among populations (Linhart and Grant, 1996). In spite of the limited attention the conservation of genetic diversity has received within practical conservation biology, knowledge of the importance of genetic variation for the survival of species is not usually 
adopted. Native biodiversity of forages is being lost at a rapid rate owing to anthropogenic causes, including habitat destruction, pollution and the spread of non-native species (Barnosky et. al., 2011).

Characterisation of various grass plants with the use of different markers allows for the documentation of particularly important plant traits. Two basic types of markers have been used i.e. non-morphological markers (molecular markers) and morphological markers (Bhat et. al., 2010). Characterisation of forages includes parameters as highly heritable traits, which can be recorded in the field and can easily be expressed in all environments and assessment data to help the evaluation of biotic and abiotic stress liability (IPGRI, 2006).

Molecular markers are essential for mapping genes of interest, marker-assisted breeding, and cloning genes using mapping-based cloning strategies (Hayashi et. al., 2004). The use of Molecular markers for tracking of loci and genome regions is now prominent among crop breeders with a large number of molecular markers linked to disease resistance traits available in most major crop species (Phillips \& Vasil, 2001; Jain et. al., 2002; Gupta \& Varshney, 2004). Large numbers of molecular markers have been isolated from genomic DNA libraries or from libraries of randomly amplified PCR fragments. The objective of this study was to characterise elephant grass (Pennisetum purpureum) harvested from selected locations in South-Western Nigeria using microsatellite based markers

\section{Materials \& Methods}

\section{Sampling sites}

Succulent leaf parts of growing young elephant grasses (Pennisetum purpureum) were harvested from wild in nine (9) selected locations (Ewekoro and Odeda in Ogun State, Ibarapa and Ido in Oyo State, Ifedore and Akure in Ondo State, Isokan, Ikoyi and Oriade in Osun State, all in south-west Nigeria. The leaf parts were immediately preserved in ethanol solution before DNA extraction study.

\section{Genomic DNA Extraction}

Genomic DNA was extracted from the grasses at the Laboratory of Animal Breeding and Genetics Department, College of Animal Science and Livestock Production, Federal University of Agriculture, Abeokuta, Nigeria using Zymo plant DNA extraction kit following the manufacturer's protocol.

DNA amplification with microsatellite markers and gel electrophoresis

Two (2) microsatellite primer pairs, originally identified in Pennisetum purpureum were used for the PCR amplification in $20 \mu$ reaction mixture containing $6 \mu \mathrm{l}$ of AccuPower $\AA$ Taq Premix (Bioneer), $1 \mu$ leach of the forward and reverse primers, $2 \mu \mathrm{l}$ of template DNA and $10 \mu \mathrm{l}$ of Nuclease free water. The PCR conditions were as follows: $94^{\circ} \mathrm{C}$ ( $3 \mathrm{~min}$ ) for initial denaturation, 35 cycles of $94^{\circ} \mathrm{C}(30 \mathrm{sec})$, specific primers and their annealing temperatures were presented in Table 1 , extension at $72^{\circ} \mathrm{C}(2 \mathrm{~min})$, final extension at $72^{\circ} \mathrm{C}(10 \mathrm{~min})$ and final hold at $4{ }^{\circ} \mathrm{C}$. The PCR product was run on $1.2 \%$ agarose gel electrophoresis stained with ethidium bromide in 1X TAE buffer at $90 \mathrm{~V}$ for 30 minutes and visualized on Trans UV and photographed in UVP DIGIDOC - IT system (UVP Bioimaging systems, USA). Bands were detected using gel analyzer software developed by Istvan Lazar.

\section{Data analysis}

The data generated by GENEMAPPER software v.3.7 (Applied Bio-systems) was transferred to Microsoft office excel 2010 package to determine the various genetic parameters. Indices such as number of alleles per locus, heterozygosity $(\mathrm{Ho})$, gene diversity $(\mathrm{He})$, polymorphic information content (PIC), genetic differentiation index (Fst) and fixation index (f) were estimated using Power-marker software according the formula of Liu and Muse (2005). Similarities between the samples were analyzed following the procedure of Peakall and Smouse (2009). A dendrogram was generated based on UPGMA using Darwin software as described by Perrier \& JacquemoundCollet (2006). 
Table 1: SSR primers used to assess genetic diversity of the grass

\begin{tabular}{|c|c|c|c|}
\hline $\begin{array}{l}\text { Primer } \\
\text { name }\end{array}$ & $\begin{array}{l}\text { Sense primer sequence } \\
\text { (Forward 5' }-3^{\prime} \text { ) }\end{array}$ & $\begin{array}{ll}\text { Antisense } & \text { primer sequence } \\
(\text { reverse } 3 & ,-5\end{array}$ & $\begin{array}{l}\text { Annealing } \\
\text { temperature } \\
\left({ }^{\circ} \mathrm{C}\right)\end{array}$ \\
\hline CTM59 & TCCTCGACATCCTCCA & GACACCTCGTAGCACTCC & 54 \\
\hline Xtxp278 & $\begin{array}{l}\text { GGG TIT CAA CTC TAG CCT ACC GAA } \\
\text { CTT CCT }\end{array}$ & $\begin{array}{l}\text { ATG CCT CAT CAT GGT TCG TTT TGC } \\
T T\end{array}$ & 50 \\
\hline
\end{tabular}

Source: Kawube et. al., 2015

\section{Results}

Test for deviation from Hardy - Weinberg equilibrium and analysis of molecular variance None of the samples from all the locations followed Hardy-Weinberg equilibrium (Table 2). Analysis of molecular variance (AMOVA) revealed that $72 \%$ of the total genetic diversity existed within individuals that give an insight of high homozygosity in the populations and $28 \%$ among individuals that give differences in character (heterozygosity) in the populations as shown in Figure 1.

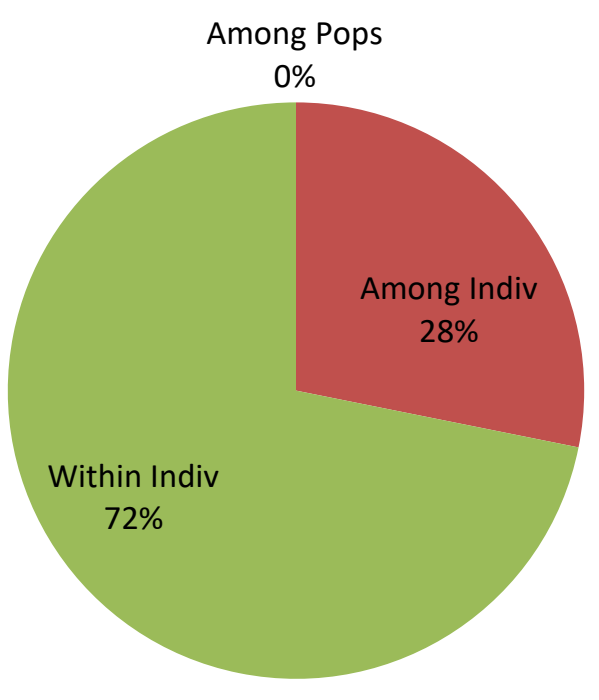

Figure 1: Analysis of molecular variance (AMOVA) to partition the levels of genetic diversity of the $P$. purpureum 


\begin{tabular}{llllll}
\multicolumn{2}{l}{ Table 2: Test for deviations between loci } & using Hardy & - Weinberg equilibrium (HWE) \\
\hline \multirow{2}{*}{ Locations } & Locus & df & Chi-Square & y & Significance \\
\hline Akure & CTM59 & 3 & 6.000 & 0.112 & Ns \\
& XTXP278 & 15 & 15.000 & 0.451 & Ns \\
Ewekoro & CTM59 & 3 & 4.000 & 0.261 & Ns \\
& XTXP278 & 3 & 4.000 & 0.261 & Ns \\
Ibarapa & CTM59 & 6 & 6.000 & 0.423 & Ns \\
& XTXP278 & 6 & 6.000 & 0.423 & Ns \\
Ido & CTM59 & 10 & 12.000 & 0.285 & Ns \\
& XTXP278 & 15 & 15.000 & 0.451 & Ns \\
Ifedore & CTM59 & 10 & 9.000 & 0.532 & Ns \\
\multirow{3}{*}{ Ikoyi } & XTXP278 & 3 & 6.000 & 0.112 & Ns \\
& CTM59 & 6 & 6.000 & 0.423 & Ns \\
Isokan & XTXP278 & 6 & 6.000 & 0.423 & Ns \\
& CTM59 & 15 & 15.000 & 0.451 & Ns \\
Odeda & XTXP278 & 10 & 12.000 & 0.285 & Ns \\
& CTM59 & 15 & 15.000 & 0.451 & Ns \\
Oriade & XTXP278 & 6 & 9.000 & 0.174 & Ns \\
& CTM59 & 3 & 4.000 & 0.261 & Ns \\
& XTXP278 & 6 & 6.000 & 0.423 & Ns
\end{tabular}

Ns: Not significant, df: Degree of freedom

Pairwise population matrix using Nei genetic distance

The lowest $D_{A}$ was observed between Isokan and Odeda populations (0.067) while the highest distance was between Ifedore and Ikoyi populations $(0.158)$ (Table 3$)$.

Summary of Private alleles among population Private alleles were observed in all populations and in both loci CTM-59 and XTXP 278. Each of the populations contained 2 private alleles in both loci except Ifedore sample (4) that had one private allele in both loci. Sample 3 of the Ikoyi population contained just one private allele which was found in CTM-59 (Table 4).

\section{Phylogenetic relationship among populations}

The phylogenetic relationships among the nine (9) elephant grass populations analyzed based on average Nei's genetic distance (DA) and hierarchical clustering yielded two distinct clusters (Figure 2). Among the cultivars, there were overlappings across the clusters. The dendrogram shows two major groups and one minor group with no clear distinction within the groups. The two distinct clusters were more related; they shared the most common ancestor. Odeda samples were the most distinct. 
Okukenu et al./ Nig. J. Biotech. Vol. 37 Num. 1 : 38-45 (June 2020)

Table 3: Pairwise population matrix of Nei genetic matrix

\begin{tabular}{|c|c|c|c|c|c|c|c|c|c|}
\hline Akure & Ewekoro & Ibarapa & Ido & Ifedore & Ikoyi & Isokan & Odeda & Oriade & \\
\hline 1.000 & & & & & & & & & Akure \\
\hline 0.000 & 1.000 & & & & & & & & Ewek \\
\hline 0.000 & 0.000 & 1.000 & & & & & & & Ibara \\
\hline 0.000 & 0.000 & 0.000 & 1.000 & & & & & & Ido \\
\hline 0.000 & 0.000 & 0.000 & 0.000 & 1.000 & & & & & Ifedo \\
\hline 0.000 & 0.000 & 0.000 & 0.000 & 0.158 & 1.000 & & & & Ikoyi \\
\hline 0.000 & 0.000 & 0.094 & 0.000 & 0.000 & 0.000 & 1.000 & & & Isoka \\
\hline 0.000 & 0.000 & 0.000 & 0.067 & 0.000 & 0.088 & 0.067 & 1.000 & & Oded \\
\hline 0.000 & 0.000 & 0.000 & 0.085 & 0.000 & 0.000 & 0.000 & 0.000 & 1.000 & Oriad \\
\hline
\end{tabular}

Table 4: Summary of Private alleles among the populations

\begin{tabular}{llllllll}
\hline Sample & Pop & \multicolumn{2}{c}{ CTM59 } & \multicolumn{1}{c}{ Xtxp278 } & $\begin{array}{l}\text { No. Loci with } \\
\text { Private Alleles }\end{array}$ & Loci with Private Alleles \\
\hline 15 & Akure & 106 & 106 & 242 & 173 & 2 & Ctm-59 Xtxp278 \\
17 & Akure & 122 & 122 & 274 & 171 & 2 & Ctm-59 Xtxp278 \\
20 & Ewekoro & 156 & 156 & 203 & 150 & 2 & Ctm-59 Xtxp278 \\
21 & Ewekoro & 309 & 174 & 149 & 149 & 2 & Ctm-59 Xtxp278 \\
7 & Ibarapa & 566 & 528 & 181 & 81 & 2 & Ctm-59 Xtxp278 \\
8 & Ibarapa & 569 & 556 & 191 & 91 & 2 & Ctm-59 Xtxp278 \\
1 & Ido & 592 & 575 & 168 & 105 & 2 & Ctm-59 Xtxp278 \\
22 & Ido & 178 & 178 & 211 & 153 & 2 & Ctm-59 Xtxp278 \\
4 & Ifedore & 559 & 509 & 80 & 80 & 1 & Ctm-59 Xtxp278 \\
5 & Ifedore & 559 & 548 & 100 & 100 & 2 & Ctm-59 Xtxp278 \\
2 & Ikoyi & 582 & 337 & 195 & 140 & 2 & Ctm-59 Xtxp278 \\
3 & Ikoyi & 578 & 563 & 80 & 210 & 1 & Ctm-59 Xtxp278 \\
9 & Isokan & 574 & 454 & 87 & 87 & 2 & Ctm-59 Xtxp278 \\
10 & Isokan & 585 & 395 & 181 & 108 & 2 & Ctm-59 Xtxp278 \\
12 & Odeda & 588 & 358 & 79 & 79 & 2 & Ctm-59 Xtxp278 \\
13 & Odeda & 574 & 500 & 33 & 210 & 2 & Ctm-59 Xtxp278 \\
18 & Oriade & 136 & 136 & 231 & 172 & 2 & \\
19 & Oriade & 181 & 83 & 205 & 153 & 2 & \\
\hline
\end{tabular}




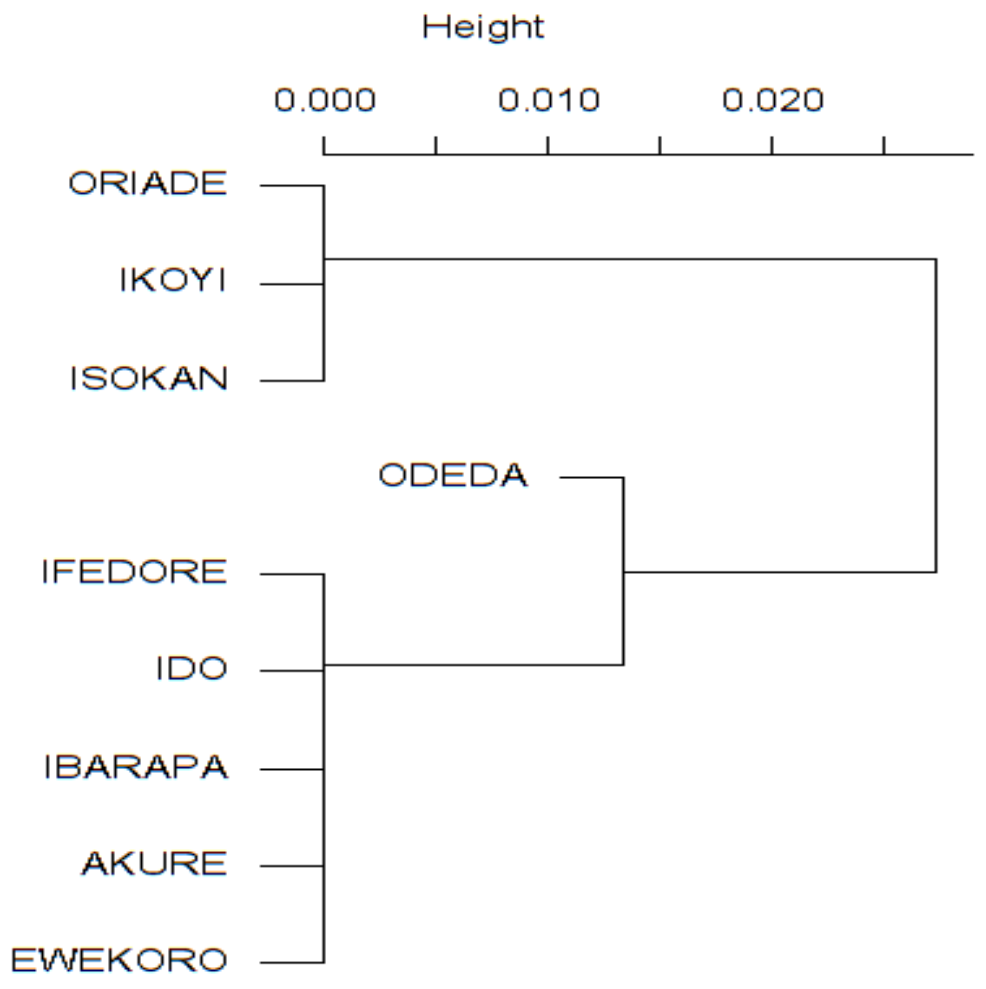

Figure 2: A dendrogram showing phylogenetic relationship among the nine locations (populations)

\section{Discussion}

Genetic characterization of cultivars is an important step in any breeding programme for selection of appropriate parental lines (Zhang et. al., 2009). Several DNA marker systems for germplasm genetic characterization are available but SSRs have been found most adequate in detecting relationships among populations as well as obtaining specific genetic fingerprints. In this study, two SSR markers were used and both gave polymorphic information which was highly informative. According to Elibariki et. al. (2013) the ability to discriminate, however, varies from one marker to another, but the two markers ((CTM-59 and XTXP-278)) are very polymorphic and informative.

HWE principle predicts how gene frequencies will be inherited unchanged from generation to generation with assumptions that there is no mutation, gene migration, selection or genetic drift (Cedric et. al., 2006). In this study there was significant deviation in the population and it might probably be due to the cultivar being deposited in a region.

AMOVA results showed that most of the diversity for the population studied resides within the population rather than between the populations which is also corroborated with heterozygosity indices. This suggested that elephant grass had tetra-ploid chromosome number which was in agreement with previous findings as reported by Azevedo et. al. (2012) who stated that "elephant grass is a highly heterozygous tetra-ploid species", the implication of which is that "variations in elephant grass cultivars were expected to be high due to its rich gene pool and wide parental diversity" 
There were alleles in the population of the elephant grass analyzed which indicated the presence of private allele i.e alleles that were unique to only one population. These were observed in all populations and on both loci. The total number of private alleles in this population was high and the higher the number of private alleles, the higher the genetic diversity. The unique alleles imply that these clones could be reservoirs of important traits or novel genes such as pests and disease resistance. The idea of using private alleles has been well documented in sorghum breeding particularly for disease and pest resistance such as sorghum shoot fly (Kamala et. al., 2009), and sorghum midge (Sharma \& Franzmann, 2001).

The measure of genetic divergence between populations within a species gives information on the genetic distance. This study showed that the population of $P$. purpureum are closely related and have a recent ancestor. The results of Nei's genetic distance measurement of the nine populations as collected from the nine locations showed that there was a phylogenetic relationship between the $P$. purpureum population, considering a population as clones from the same place of collection (Nei, 1987).

Further classification into phylogenetic reconstruction using the Neighbour Joining method grouped the $P$. purpureum populations into two major phylogenetic clusters and one minor cluster. However, the contrary was true in this study and the clusters were not distinct, and this can be attributed to the materials under circulation share ancestry especially when $P$. purpureum grass is closely propagated, and the farmers freely exchange planting materials. These findings agreed with the reports of Nei (1987) and Wanjala et. al. (2013) where the $P$. purpureum clones under those studies also clustered into two major clusters and one minor cluster

\section{Acknowledgement}

Appreciation goes to Mrs. Sanda, Foyeke of the Department of Animal Breeding and Genetics, College of Animal Science and Livestock Production, Federal University of Agriculture, Abeokuta, Ogun State, Nigeria for her assistance in the laboratory analysis towards the successful completion of this work

\section{References}

Azevedo, A.L.S., Costa, P.P., Machado, J.C., Machando, M.A., Pereira, A.V. and Ledo. F.J.S. (2012). Cross species amplification of Pennisetum glaucum microsatellite markers in Pennisetum purpureum and genetic diversity of Napier grass accessions. Crop Science 4: 1776-1785.66

Barnosky, A. D., Matzke, N., Tomiya, S., Wogan, G. O. U., Swartz, B., Quental, T. B., Marshall, C., McGuire, J. L., Lindsey, E. L., Maguire, K. C., Mersey, B. and Ferrer, E. A. (2011). Has the Earth's sixth mass extinction already arrived? Nature, 471, 51-57.

Bhat, Z. A., Dhillon, W. S., Rashid, R., Bhat, J. A., Dar, W. A. and Ganaie, M. Y. (2010). The role of molecular markers in improvement of fruit crops. Not. Sci. Biol. 2 (2): 22-30

Burton, G. W. (1999). Hybrids between napier grass and cattail millet. J. Hered. 35: 227-232.

Cedric, M., Viviane L., Issoufou K., Fabrice S. and Yves V. (2006). Diversity of wild and cultivated pearl millet accessions (Pennisetum glaucum [L.] R. Br.) in Niger assessed by microsatellite markers. Theoretical and Applied Genetics 114: 49-58.

Elibariki, M. Hanson, C. Harish, K. and Nicolas, Y. (2013). Integration of simple sequence repeat (SSR) marker into a molecular linkage map of common bean (Phaseolus vulgaris L.). J. Hered 91: 429-434.

Gupta, P.K. and Varshney, R.K. (2004). Cereal Genomics: An Overview. In Cereal Genomics, Gupta, P.K., Varshney, R.K., Eds.; Kluwer Academic Press: Dordrecht, The Netherlands, p. 639.

Hayashi, K., Hashimoto, N., Daigen, M. and Ashikawa, I. (2004). Development of PCR-based SNP markers for rice blast resistance genes at the Piz locus. Theor. Appl. Genet. 108: 1212-1220.

International Plant Genetic Resources Institute (IPGRI) (2006). Descriptors for elephant grass (Pennisetum purpureum.). Rome, Italy. 
Jain, S.M., Brar, D.S. and Ahloowalia, B.S. (2002). Molecular Techniques in Crop Improvement, 2nd ed.; Kluwer Academic Publishers: Dordrecht, The Netherlands, p. 772.

Jauhar, P. P. (1981). Cytogenetics and breeding of pearl millet and related species. (Alan R. Liss, Inc. Progress and Topics in Cytogenetics, Volume $1,1981)$.

Kamala, V., Sharma, H.C., Manohar, R.D., Varaprasad, K.S. and Bramel, P.J. (2009). Wild relatives of sorghum as sources of resistance to sorghum shoot fly, Atherigona soccata. Plant Breeding 128:137-1472.

Kawube, G., Alicai, T., Wanjala, B., Njahira, M., Awalla, J. and Skilton, R. (2015). Genetic diversity in napier grass (Pennisetum purpureum) assessed by SSS markers. Journal of Agricultural Science 7 (7) 147-155.

Linhart, Y. B. and Grant, M. C. (1996). Evolutionary significance of local genetic differentiation in plants. Annual Review of Ecology and Systematics 27:237-277.

Loveless, M. D. and Hamrick, J. L. (1984). Ecological determinants of genetic structure in plant populations. Annual Review of Ecology and Systematics 15:65-95.

Nei, M. (1987). Genetic distance between populations. American Naturalist 106:283-292.

Peakall, R. and Smouse, P. E. (2009). GENALEX 6: Genetic Analysis in Excel. Population genetic software for teaching and research. Molecular Ecology Notes 6:288-295.

Perrier, X. and Jacquemoud-Collet, J. P. (2006) DARwin Software. http://darwin.cirad.fr/darwin.

Phillips, R.L. and Vasil, I.K. (2001). DNA-Based Markers in Plants. In DNA-Based Markers in Plants, Kluwer Academic Publishers: Dordrecht, The Netherlands, p. 497.

Sharma, H. C., and Franzmann, B. A. (2001). Host-plant preference and oviposition responses of the sorghum midge, Stenodiplosis sorghicola (Coquillett) (Dipt., Cecidomyiidae) towards wild relatives of sorghum. J. Appl. Entomol. 125: 109114.
Singh, B. P., Singh, H. P. and Obeng, E. (2009). In Biofuel Crops: Production, Physiology and Genetics; Singh, B.P., Ed.; CAB International: Fort Valley State University, Fort Valley, GA, USA, 2013; 271-291 pp.

Wanjala, B.W., Obonyo, M., Wachira, F.N., Muchugi, A., Mulaa, M., Harvey, J., Skilton, R.A., Proud, J. and Hanson, J. (2013). Genetic diversity in Napier grass (Pennisetum purpureum) cultivars: implications for breeding and conservation. Annals of Botany Company plt022; doi: 10.1093/ aobpla/plt022

Zhang, Z., Deng, Y., Tan, J., Hu, S., Yu, J. and Xue, Q. (2007). A genome-wide microsatellite polymorphism database for the indica and japonica rice. DNA Research 14: 37-45. 